\title{
PENGARUH LINGKUNGAN KELUARGA DAN DISIPLIN BELAJAR TERHADAP HASIL BELAJAR MATEMATIKA SISWA KELAS IV SD NEGERI SE-KECAMATAN BENER TAHUN AJARAN 2020/2021
}

\author{
Indah Novita Sari ${ }^{1}$, Ngatman $^{2}$, Rokhmaniyah $^{3}$ \\ Universitas Sebelas Maret \\ indahnovitasari@student.uns.ac.id
}

\section{Article History}

accepted 1/11/2021

approved 1/12/2021

published 31/12/2021

\begin{abstract}
The study aimed to determine positive effect of: (1) family environment on mathematics learning outcomes, (2) learning discipline on mathematics learning outcomes, and (3) the family environment and learning discipline on the mathematics learning outcomes to fourth grade students of public elementary schools. The research was correlational quantitative method and multiple regression analysis. The results showed that: (1) there was $8.12 \%$ positive effect of family environment on the mathematics learning outcomes of fourth grade elementary school students. (2)There was $1.78 \%$ effect of learning discipline on student's mathematics learning outcomes. (3)There was $9.9 \%$ effect of the family environment and learning discipline on mathematics learning outcomes. It concludes that there is positive effect between the family environment and learning discipline on the mathematics learning outcomes to fourth grade students of public elementary schools in Bener Sub-district in academic year of 2020/2021.
\end{abstract}

Keywords: family environment, learning discipline, mathematics learning outcomes

\begin{abstract}
Abstrak
Penelitian ini bertujuan untuk membuktikan ada tidaknya (1) pengaruh positif lingkungan keluarga terhadap hasil belajar matematika kelas IV SD; (2) pengaruh positif disiplin belajar terhadap hasil belajar matematika kelas IV SD; (3) pengaruh positif lingkungan keluarga dan disiplin belajar terhadap hasil belajar matematika kelas IV SD. Penelitian ini merupakan penelitian kuantitatif korelasi menggunakan analisis regresi berganda. Hasil penelitian Pertama, terdapat pengaruh positif antara lingkungan keluarga terhadap hasil belajar matematika kelas IV SD sebesar $8,12 \%$. Kedua, terdapat pengaruh antara disiplin belajar terhadap hasil belajar matematika kelas IV SD sebesar 1,78\%. Ketiga, terdapat pengaruh pengaruh lingkungan keluarga dan disiplin belajar terhadap hasil belajar matematika sebesar 9,9\%. Dengan demikian, dapat disimpulkan bahwa terdapat pengaruh positif antara lingkungan keluarga dan disiplin belajar terhadap hasil belajar matematika siswa kelas IV SDN se-Kecamatan Bener tahun ajaran 2020/2021 secara bersama-sama maupun terpisah.
\end{abstract}

Kata kunci: lingkungan keluarga, disiplin belajar, hasil belajar matematika 


\section{PENDAHULUAN}

Pendidikan merupakan salah satu bidang penting dalam menciptakan kemajuan bangsa. Pendidikan yang kuat akan mendukung bangsa untuk terus maju dan berkembang, secara tidak langsung kemajuan suatu bangsa dapat dilihat dari kualitas pendidikan yang diperoleh masyarakatnya. Berhasil atau tidaknya suatu proses pendidikan dapat dilihat dari hasil belajar siswa selama proses pembelajaran.

Pada proses pembelajaran siswa akan mempelajari berbagai macam mata pelajaran. Salah satu mata pelajaran yang wajib dipelajari siswa yaitu matematika. Hal ini sesuai dengan Undang-Undang No 20 Tahun 2003 Pasal 37 Ayat 1 menyatakan bahwa matematika merupakan salah satu mata pelajaran yang wajib dipelajari oleh peserta didik pada kurikulum pendidikan sekolah dasar dan menengah. Matematika merupakan suatu bahan kajian yang memiliki objek abstrak dan dibangun melalui proses penalaran deduktif, yaitu kebenaran suatu konsep yang diperoleh sebagai akibat logis dari kebenaran sebelumnya yang telah diterima, sehingga kebenaran antar konsep dalam matematika bersifat kuat dan jelas (Wahyudi, 2015).

Namun, masih banyak orang yang memandang matematika sebagai mata pelajaran yang sulit untuk dipelajari, hal ini sejalan dengan pendapat Siregar (2017), menyatakan bahwa matematika merupakan pelajaran yang cukup sulit, dengan demikian pelajaran matematika penting untuk dipelajari. Hal ini dibuktikan dari hasil wawancara dan observasi yang dilakukan oleh peneliti di SD N Kaliwader pada tanggal 21 Oktober 2020 menunjukkan bahwa hasil belajar yang diperoleh siswa juga belum maksimal, hal ini dapat dilihat dari hasil ulangan matematika siswa yang masih terdapat beberapa siswa yang belum tuntas KKM.

Keberhasilan belajar siswa di pengaruhi oleh beberapa faktor. Menurut Islamuddin (2012) faktor yang memengaruhi keberhasilan belajar siswa yaitu faktor internal dan eksternal. Salah satu faktor internal yang melekat dalam diri siswa berupa faktor sikap, salah satunya yaitu sikap. disiplin. Sedangkan faktor eksternal yang tidak kalah berpengaruh pada keberhasilan siswa dalam proses pembelajaran berupa faktor lingkungan sosial yaitu lingkungan keluarga.

lingkungan mampu mendorong keberhasilan belajar siswa (Yarmyani dan Afrila, 2018). Pada lingkungan keluarga inilah anak menerima sejumlah nilai dan norma yang ditanamkan sejak kecil. Slameto (2015) menjelaskan bahwa keberhasilan belajar anak dipengaruhi oleh beberapa faktor salah satunya lingkungan keluarga yang meliputi: cara orang tua mendidik anak, hubungan antaranggota keluarga, keadaan rumah, kondisi ekonomi keluarga, perhatian orang tua, dan latar belakang kebudayaan keluarga. Keberhasilan belajar anak dapat terwujud apabila unsur-unsur di atas dapat terpenuhi.

Lingkungan keluarga yang baik akan membuat anak termotivasi untuk belajar secara giat dan semangat. Namun pada kenyataanya masih terdapat lingkungan keluarga yang kurang kondusif untuk belajar. Selain itu, kurangnya komunikasi yang terbuka antara anak dengan orang tua maupun orang tua dengan guru. Berdasarkan penjelasan di atas, indikator yang menunjukkan adanya kontribusi lingkungan keluarga meliputi: cara orang tua mendidik anak, hubungan antaranggota keluarga, keadaan rumah, kondisi ekonomi keluarga, perhatian orang tua, dan latar belakang kebudayaan keluarga.

Selain dipengaruhi oleh faktor eksternal hasil belajar juga dipengaruhi oleh faktor internal salah satunya yaitu disiplin belajar. Disiplin belajar merupakan syarat yang sangat penting dan menentukan keberhasilan seorang siswa dalam proses belajar (Yunita, dkk, 2019). Disiplin belajar merupakan suatu perilaku atau kondisi yang menyatu dalam diri seseorang yang timbul karena proses pembinaan di dalam keluarga, pendidikan, dan pengalaman yang menunjang dalam hal belajar. Perilaku tersebut dapat ditunjukkan melalui nilai-nilai ketaatan, kepatuhan, kesetiaan, 
keteraturan atau ketertiban terhadap berbagai peraturan dan ketentuan (Asmadi, 2017).

Namun pada kenyataanya masih banyak siswa yang memiliki sikap kurang disiplin, hal ini ditunjukkan dari sikap siswa yang terlambat mengumpulkan tugas, belum maksimal dalam memanfaatkan waktu belajar di rumah, dan belum disiplin dalam mematuhi aturan di sekolah.Oleh karena itu, untuk mengetahui tingkat disiplin belajar siswa dapat dilakukan menggunakan indikator sebagai berikut. 1) rajin dan teratur belajar; 2) mampu mengatur waktu belajar di rumah; 3) mematuhi aturan di sekolah; 4) mengajak teman menjaga ketertiban kelas; 5) ketertiban diri saat belajar; dan 6) perhatian yang baik saat belajar.

Berdasarkan uraian di atas, peneliti bermaksud untuk melakukan penelitian untuk membuktikan ada atau tidaknya (1) pengaruh positif lingkungan keluarga terhadap hasil belajar matematika; (2) pengaruh positif disiplin belajar terhadap hasil belajar matematika; (3) pengaruh positif lingkungan keluarga dan disiplin belajar terhadap hasil belajar matematika siswa kelas IV SDN Se-Kecamatan Bener Tahun Ajaran 2020/2021.

\section{METODE}

Penelitian ini merupakan penelitian kuantitatif korelasi menggunakan analisis regresi berganda. Penelitian korelasi adalah penelitian yang melibatkan hubungan satu atau lebih variabel dengan satu atau lebih variabel lain (Purwanto, 2012). Analisis regresi berganda dilakukan dengan menguji pengaruh variabel bebas yaitu lingkungan keluarga dan disiplin belajar terhadap variabel terikat yaitu hasil belajar matematika kelas IV SD. Populasi penelitian ini yaitu siswa kelas IV SDN se-Kecamatan Bener sejumlah 678 siswa dengan sampel sebanyak 252 siswa di sebelas SDN di Kecamatan Bener. Teknik pengambilan sampel yang digunakan yaitu random sampling.

Teknik pengumpulan data dilakukan dengan menggunakan instrumen angket dan tes. Angket digunakan untuk mengumpulkan data lingkungan keluarga dan disiplin belajar dan tes digunakan untuk mengumpulkan data hasil belajar matematika siswa kelas IV SD. Instrumen terlebih dahulu diuji validitas dan reliabilitasnya sebelum akhirnya digunakan dalam penelitian. Pengumpulan data untuk uji instrumen dilakukan pada 37 siswa kelas IV di dua sekolah yang bukan merupakan sampel.

Teknik analisis data dilakukan dengan uji prasyarat dan uji hipotesis. Uji prasyarat penelitian ini dilakukan uji normalitas, uji linieritas, dan uji multikolinieritas. Sementara, uji hipotesis dilakukan dengan uji regresi berganda, uji korelasi berganda, dan sumbangan efektif.

\section{HASIL DAN PEMBAHASAN}

Penelitian dilakukan dengan memberikan angket lingkungan keluarga dan disiplin belajar serta soal tes matematika kepada siswa kelas IV SD yang menjadi sampel. Uji persyaratan pada penelitian ini ada tiga macam yaitu uji normalitas, uji liniearitas, dan uji multikolinieritas.

Pada penelitian ini diperoleh data berupa nilai Asymp. Sig. (2-tailed) untuk variabel lingkungan keluarga 0,118 , disiplin belajar 0,254 , dan hasil belajar matematika 0,103 Data dikatakan normal apabila nilai signifikansi $>0,05$. Berdasarkan hasil analisis ketiga variabel tersebut nilai signifikansi $>0,05$, sehingga data variabel lingkungan keluarga, variabel disiplin belajar dan hasil belajar matematika berdistribusi normal.

Berdasarkan uji linieritas yang telah dilakukan dapat diketahui bahwa pada uji linieritas variabel hasil belajar matematika dan lingkungan keluarga didapatkan signifikansinya 0,455>0,05 sehingga dapat disimpulkan bahwa terdapat hubungan linear antara hasil belajar matematika dan variabel lingkungan keluarga. Hasil uji linearitas variabel hasil belajar matematika dan disiplin belajar diperoleh signifikansi 
$0,292>0,05$ sehingga dapat disimpulkan bahwa terdapat hubungan linear antara hasil belajar matematika dan variabel disiplin belajar.

Uji multikolinieritas menunjukkan bahwa setiap variabel bebas memiliki nilai tolerance 0,862 dan nilai VIF 1,160. Oleh karena itu, dapat disimpulkan bahwa tidak terjadi multikolinieritas dalam variabel lingkungan keluarga dan disiplin belajar pada model regresi linear berganda karena nilai tolerance $<0,10$ serta nilai VIF $<10$.

Pengajuan hipotesis pada penelitian ini menggunakan analisis korelasi berganda dan regresi berganda. Pengajuan ini digunakan untuk menguji adanya pengaruh antara lingkungan keluarga $\left(X_{1}\right)$ dan disiplin belajar $\left(X_{2}\right)$ terhadap hasil belajar matematika siswa kelas IV SD (Y).

Tabel 1. Hasil Uji Korelasi Berganda Correlations

\begin{tabular}{cllrrr}
\hline Control Variables & & LK & \multicolumn{1}{c}{ DB } & \multicolumn{1}{c}{ HB } \\
\hline \multirow{2}{*}{ Lingkungan } & Correlation & 1.000 & .372 & .302 \\
& Keluarga & Significance (2-tailed) &. & .000 & .000 \\
& & df & 0 & 254 & 254 \\
-none- $^{a}{ }^{a}$ & Cisiplin & Correlation & .372 & 1.000 & .193 \\
& Belajar & Significance (2-tailed) & .000 &. & .002 \\
& df & 254 & 0 & 254 \\
& Hasil & Correlation & .302 & .193 & 1.000 \\
& Belajar & Significance (2-tailed) & .000 & .002 &. \\
& df & 254 & 254 & 0 \\
\hline
\end{tabular}

Berdasarkan tabel korelasi berganda di atas diketahui nilai $r$ hitung $=0,302$, sedangkan $r$ tabel $(N=254)$ yaitu 0,123 . Oleh karena itu, dapat disimpulkan bahwa nilai $r$ hitung $(0,302)>r$ tabel $(0,123)$ yang berarti terdapat pengaruh antara lingkungan keluarga terhadap hasil belajar matematika. Hasil analisis koefisien korelasi antara variabel lingkungan keluarga terhadap hasil belajar matematika sebesar 0,302, artinya terjadi hubungan dengan kategori moderat/ sedang. Nilai signifikansi sebesar $0,000<$ 0,05, maka hipotesis penelitian ini dapat diterima, artinya lingkungan keluarga mempunyai pengaruh yang signifikan terhadap hasil belajar matematika. Untuk variabel disiplin belajar diketahui nilai $r$ hitung $=0,193$, sedangkan $r$ tabel $(N=254)$ yaitu 0,123 . Oleh kerena itu, dapat disimpulkan bahwa nilai $r$ hitung $(0,193)>r$ tabel $(0,123)$ yang berarti terdapat pengaruh antara disiplin belajar terhadap hasil belajar matematika. Hasil analisis koefisien korelasi antara variabel disiplin belajar terhadap hasil belajar matematika sebesar 0,193, artinya terjadi hubungan dengan kategori lemah. Nilai signifikansi sebesar $0,000<0,05$, maka hipotesis penelitian ini dapat diterima. Jadi, dapat disimpulkan bahwa terdapat pengaruh yang signifikan antara disiplin belajar terhadap hasil belajar matematika.

Tabel 2. Hasil Uji Regresi Berganda

\begin{tabular}{|c|c|c|c|c|c|c|c|c|}
\hline \multicolumn{9}{|c|}{ Model Summary } \\
\hline \multirow[t]{2}{*}{ Model } & \multirow[t]{2}{*}{$\mathrm{R}$} & \multirow{2}{*}{$\begin{array}{c}\mathrm{R} \\
\text { Square }\end{array}$} & \multirow{2}{*}{$\begin{array}{c}\text { Adjusted } \\
\text { R } \\
\text { Square }\end{array}$} & Std. & \multicolumn{4}{|c|}{ Change Statistics } \\
\hline & & & & $\begin{array}{c}\text { Error } \\
\text { of the } \\
\text { Estimate }\end{array}$ & $\begin{array}{c}\mathrm{R} \\
\text { Square } \\
\text { Change }\end{array}$ & $\begin{array}{c}\mathrm{F} \\
\text { Change }\end{array}$ & $\mathrm{df1} \quad \mathrm{df} 2$ & $\begin{array}{c}\text { Sig. } \\
\text { F } \\
\text { Change }\end{array}$ \\
\hline 1 & .314 & .099 & .092 & 16.448 & .099 & 13.858 & 253 & .000 \\
\hline
\end{tabular}


Berdasarkan perhitungan dapat diketahui Sig $F$ change sebesar 0,000 . Nilai Sig $F$ change $<\alpha(0,000<0,05)$, artinya terdapat pengaruh yang signifikan antara lingkungan keluarga dan disiplin belajar terhadap hasil belajar matematika. Selain itu, diketahui hasil koefisien korelasi anatara lingkungan keluarga dan disiplin belajar terhadap hasil belajar matematika sebesar 0,314 yang artinya terdapat hubungan dengan kategori moderat/ sedang.

Berdasarkan kontribusi variabel prediktor terhadap variabel prediksi dapat diketahui dengan menghitung sumbangan relatif (SR) dan sumbangan efektif (SE). SR diketahui sebesar $100 \%$, sedangkan SE dihitung dengan cara mengalikan SR dengan koefisien determinan $\left(R^{2}\right)$ yaitu sebesar $9,9 \%$. Dengan demikian, dapat disimpulkan bahwa kontribusi lingkungan keluarga dan disiplin belajar terhadap hasil belajar matematika adalah 9,9\%, sedangkan 90,1\% lainnya dipengaruhi oleh faktor lain di luar penelitian ini, misalnya: minat, motivasi, sikap, kecerdasan, lingkungan sekolah, lingkungan masyarakat dan lain sebagainya. Hal ini menunjukkan bahwa semakin tinggi tingkat kontribusi lingkungan keluarga dan disiplin belajar yang ada pada siswa maka akan semakin tinggi pula hasil belajar matematika yang akan diraih siswa. Sebaliknya, semakin rendah tingkat kontribusi lingkungan keluarga dan disiplin belajar yang ada pada siswa akan berdampak pada semakin rendahnya hasil belajar matematika yang diperoleh siswa.

Hasil akhir dari penelitian ini yaitu terdapat pengaruh yang positif dan signifikan antara lingkungan keluarga dan disiplin belajar terhadap hasil belajar matematika siswa kelas IV SD Negeri se-Kecamatan Bener tahun ajaran 2020/2021. Hal ini sesuai dengan penelitian yang dilakukan oleh Asmadi (2017) yang berjudul "Pengaruh Disiplin Belajar dan Lingkungan Keluarga terhadap Hasil Belajar Matematika Siswa Kelas V SDN Gugus Ki Hajar Dewantara Mijen Semarang" diperoleh $f_{\text {hitung }}$ 36,7 dan $f_{\text {tabel }}$ 3,07 sehingga $f_{\text {hitung }}>f_{\text {tabel. }}$. Jadi, dapat disimpulkan bahwa terdapat pengaruh yang positif disiplin belajar dan lingkungan keluarga terhadap hasil belajar.

Hasil analisis penelitian ini dengan hasil penelitian yang telah dilakukan sebelumnya memiliki kesesuaian. Dengan demikian, membuktikan bahwa faktor lingkungan keluarga dan disiplin belajar secara bersama-sama berpengaruh terhadap hasil belajar siswa. Hasil belajar akan semakin baik apabila faktor-faktor yang memengaruhi belajar dapat ditangani dengan baik. Berdasarkan analisis yang dilakukan dalam penelitian ini, diketahui sumbangan variabel lingkungan keluarga dan disiplin belajar secara bersama-sama terhadap hasil belajar matematika siswa kelas IV SDN se-Kecamatan Bener tahun ajaran 2020/2021 yaitu sebesar 9,9\%, sedangkan $90,1 \%$ sisanya dipengaruhi oleh faktor lain di luar penelitian ini misalnya minat, motivasi, sikap, kecerdasan, lingkungan sekolah, lingkungan masyarakat dan lain sebagainya.

\section{SIMPULAN}

Berdasarkan hasil penelitian dan pembahasan mengenai pengaruh lingkungan keluarga dan disiplin belajar terhadap hasil belajar matematika siswa kelas IV SDN seKecamatan Bener tahun ajaran 2020/2021 dapat ditarik kesimpulan sebagai berikut: (1) lingkungan keluarga berpengaruh positif dan signifikan terhadap hasil belajar matematika siswa kelas IV SDN se-Kecamatan Bener dengan besar sumbangan $8,12 \% \%$. Semakin tinggi tingkat kontribusi lingkungan keluarga terhadap proses belajar anak, maka akan semakin tinggi pula hasil belajar matematika siswa kelas IV SD. (2) disiplin belajar berpengaruh positif dan signifikan terhadap hasil belajar matematika siswa kelas IV SDN se-Kecamatan Bener dengan besar sumbangan 1,78\%. Tingkat disiplin belajar siswa yang semakin tinggi, akan semakin tinggi pula hasil belajar matematika siswa kelas IV SD.(3) Lingkungan keluarga dan disiplin belajar berpengaruh positif terhadap hasil belajar matematika siswa kelas IV SD Negeri seKecamatan Bener tahun ajaran 2020/2021 dengan besar sumbangan 9,9\%. Semakin 
tinggi peran lingkungan keluarga dan disiplin belajar, maka semakin tinggi pula hasil belajar matematika siswa kelas IV SD.

\section{DAFTAR PUSTAKA}

Asmadi, B, B,B. (2017). Pengaruh Disiplin Belajar dan Lingkungan Keluarga Terhadap Hasil Belajar Matematika Siswa Kelas V SDN Gugus Ki Hajar Dewantara Mijen Semarang. Skripsi. Fakultas Ilmu Pendidikan Universitas Negeri Semarang.

Depdikbud. (2003). Undang- undang No 20 Tahun 2003, tentang Sistem Pendidikan Nasional. Jakarta: Depdiknas.

Islamuddin, H. (2012). Psikologi Pendidikan. Yogyakarta: Pustaka Pelajar.

Purwanto. (2012). Metode Penelitian Kuantitatif. Yogyakarta: Pustaka Pelajar.

Siregar, N. R. (2017). Persepsi Siswa Pada Pelajaran Matematika: Studi Pendahuluan Pada Siswa Yang Menyenangi Game. Prosiding Temu Ilmiah X Ikatan Psikologi Perkembangan Indonesia. Yogyakarta: Universitas Gadjah Mada.

Slameto. (2015). Belajar dan Faktor-Faktor yang Mempengaruhi. Jakarta: PT Rineka Cipta.

Wahyudi. (2015). Panduan Pembelajaran Matematika Sekolah Dasar (Untuk Guru dan Calon Guru SD). Surakarta: UNS Press.

Yarmayani dan Afrila. (2018). Analisis Faktor Lingkungan Belajar yang Mempengaruhi Hasil Belajar Siswa. Jurnal Ilmiah DIKDAYA. Universitas Batanghari.

Yunita, dkk. (2019). Analysis of Emotional Intelligence, Environment and Discipline on Student Learning Achievement. Journal for Quality in Public Health, 3 (1). 